\title{
The study of the usage of coral and limestone aggregates as asphaltic layer on coastal structures
}

\author{
Adelia Dwidarma Nataadmadja ${ }^{1,{ }^{*}}$, Oki Setyandito ${ }^{1}$, Fiona Maida Basrian ${ }^{1}$, and Michael Grashinton Kurniawardhani ${ }^{1}$ \\ ${ }^{1}$ Civil Engineering Department, Bina Nusantara University, 11480 Jakarta, Indonesia
}

\begin{abstract}
Indonesia is a maritime country with the second longest coastline in the world. Any structures constructed along the coastline, such as pavement layer on sea dike, must be able to resist the hydrodynamic forces from the waves, such as the overtopping wave. It is necessary to find an aggregate to be used as surfacing layer for sea dike and/or flexible pavement that can withstand these (compressive) forces. This research analyses the feasibility of two natural aggregates, namely the coral and limestone aggregates, to be used as an ingredient for asphalt surface layer on coastal structures. Asphalt mix samples were prepared by using these two aggregates with various percentage of asphalt. The Marshall stability, flow, and the compressive force $\left(\mathrm{F}_{\text {lab }}\right)$ of the prepared samples were tested in the laboratory. The stability and the flow of asphalt samples were tested to verify that the asphalt mix satisfies the requirements specified by Standar Nasional Indonesia 06-2489-1991. Moreover, this research also calculates the overtopping waves by varying the height and the period of the waves. The results were then converted as a compressive force $\left(F_{w a v e}\right)$ and compared to the $F_{\text {lab }}$ to see whether the prepared samples could resist the calculated $F_{\text {wave }}$.
\end{abstract}

\section{Introduction}

Indonesia is a maritime country with the second longest coastline in the world, and hence, it is important to ensure that the infrastructure built around the coastline is resistant to the hydrodynamic forces from the waves, such as the overtopping wave. One of the structures that directly face the sea wave is the sea dike, which is built with the aim to protect coastal areas from the water pressure. It has sloping sides and watertight protection surface layer, which can be made from concrete, asphalt, asphaltic concrete or synthetic material [1-4].

Asphalt layer has been commonly used as the surfacing layer on the dyke and research project has been undertaken to analyse the relationship between the dyke slope and the percentage of void in asphalt mixture [5]. It was found that the higher the dyke slope, the higher the percentage of void in asphalt due to the increasing difficulty in the compaction process will be. Additionally, the stiffness of the protection layer significantly affects the capacity of the layer to resist sea wave. More studies are required to be conducted to assess the capability of asphalt mixture to be used as protection layer of sea dike as the wave in Indonesia's coastal area might be different to other countries, and hence, adjustment in design might be needed to suit the local condition.

Additionally, due to the increasing construction cost, it is necessary to utilize locally available material (wherever possible) to minimize the transportation cost of materials. In Indonesia, both coral and limestone aggregates are available in abundance and in a close proximity. Therefore, this paper focuses on studying the feasibility of two natural aggregates, coral and limestone aggregates, as an ingredient of asphalt mixture to be used as the protection layer of sea dike structure against the overtopping wave.

\section{Limestone and coral aggregates}

There are two natural aggregates used in this research, coral and limestone aggregates. Both of them are categorized as organic sedimentary rock and mainly consist of calcium carbonate $\left(\mathrm{CaCO}_{3}\right)$ [6]. However, their forming process is different which results in diversity in the rock form. Limestone aggregates are crystallized rock, while the coral aggregates are more porous [7].

Limestone aggregates have been commonly used as construction materials, including as filler in asphalt mixture, and have been proven to have some advantages for pavement performance, such as reduces the potential of asphalt to deform at high temperatures and alters the plastic properties of clay fines to improve moisture stability and durability [8]. They have high affinity for asphalt and low affinity for water, so that they can bond well with asphalt. Additionally, the usage of certain limestone aggregates used in the coarse aggregate fraction of asphalt concrete wearing course can increase mix stability and resistance to moisture damage $[9,10]$.

Coral aggregates have been used as construction material for road pavements, especially in Pacific islands [11-13]. In Indonesia, a research project has shown that coral aggregates have also been used in asphalt mixture, although it was found that additive has to be added to

Corresponding author: anataadmadja@binus.edu 
improve the quality of the bond between the asphalt and the coral aggregates [7].

\section{Wave run up and overtopping}

The wave run-up height is defined as the vertical difference between the highest point of wave run-up and the still water level [14]. Due to the stochastic nature of the incoming waves, each wave will give a different runup level. If only $2 \%$ of the waves reach the crest of a coastal structure, the crest and inner slope do not need specific protection measures. Wave run-up had previously been the focus in research projects. However, in the past decades, the design or safety assessment has been changed to allowable overtopping instead of wave run-up.

Wave overtopping is one of the most important hydraulic responses of a breakwater. It occurs when the top of the structure is lower than the run-up level during maximum wave [15]. Wave overtopping significantly affects its functional efficiency and to a lesser extent, its structural safety [16]. It has also been the major cause of the inner slope of sea dikes [17-18]. Therefore, it is important to ensure that the design of sea dikes can resist the compressive force generated by this wave overtopping.

\section{Experimental design}

\subsection{Material}

There are two aggregates used in this research, coral and limestone aggregates as shown in Figures 1 and 2. Six asphalt samples were constructed for each type of aggregates and for each percentage of asphalt content $(4.5 \%, 5.5 \%$, and $6 \%)$. Three samples were used for Marshall Stability and Flow Test and the other three were used for Compressive Strength Test. The aggregates were crushed into four sizes, as shown in Table 1. The coarsest aggregates are Aggregate I and the finest aggregates are Aggregate IV. The asphalt samples were then constructed by using the asphalt mix design used in [19], as shown in Table 2. The samples were compacted 75 times on each side.

It is important to note that the limestone aggregates used in this research were covered by a thin layer of particles, although they did not interrupt the adhesion between the aggregates and the asphalt.

Table 1. Grading of aggregates

\begin{tabular}{|c|c|c|}
\hline Aggregate & Passed Sieve No. & $\begin{array}{c}\text { Retained by Sieve } \\
\text { No. }\end{array}$ \\
\hline I & $\begin{array}{c}3 / 4 ” \\
(19,1 \mathrm{~mm})\end{array}$ & $\begin{array}{c}3 / 8 " \\
(9,6 \mathrm{~mm})\end{array}$ \\
\hline II & $\begin{array}{c}3 / 8 ” \\
(9,6 \mathrm{~mm})\end{array}$ & $\begin{array}{c}\# 8 \\
(2,4 \mathrm{~mm})\end{array}$ \\
\hline III & $\begin{array}{c}\# 8 \\
(2,4 \mathrm{~mm})\end{array}$ & $\begin{array}{c}\# 16 \\
(1,2 \mathrm{~mm})\end{array}$ \\
\hline IV & $\begin{array}{c}\# 16 \\
(1,2 \mathrm{~mm})\end{array}$ & $\begin{array}{c}\# 200 \\
(0,075 \mathrm{~mm})\end{array}$ \\
\hline
\end{tabular}

Table 2. The composition of asphalt mix design

\begin{tabular}{|c|c|c|c|c|c|}
\hline \multicolumn{2}{|c|}{ Asphalt Content } & \multicolumn{4}{|c|}{ Weight of Aggregate (gr) } \\
\hline $\mathbf{\%}$ & $\mathbf{g r}$ & I & II & III & IV \\
\hline 4.5 & 52.87 & 242 & 193 & 181 & 476 \\
\hline 5.5 & 66 & 242 & 193 & 181 & 476 \\
\hline 6.0 & 71.62 & 242 & 193 & 181 & 476 \\
\hline
\end{tabular}

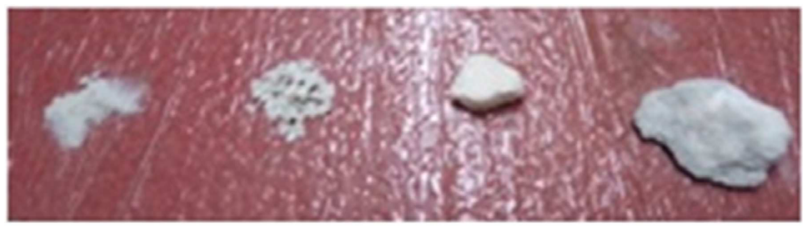

Fig. 1. Coral aggregates

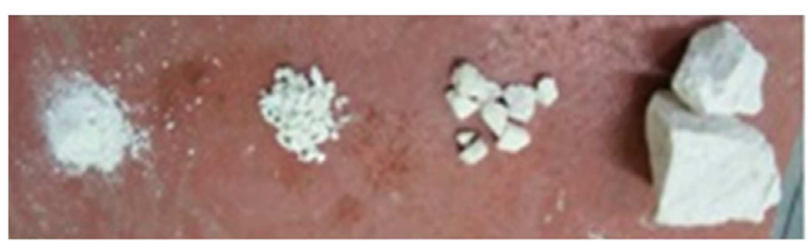

Fig. 2. Limestone aggregates

\subsection{Laboratory tests}

There are a number of laboratory tests conducted for this research, namely the Marshall Stability and Flow Test, which was conducted according to Standar Nasional Indonesia (SNI) 06-2489-1991, and Compressive Strength Test, which was conducted according to SNI 03-1974-1990. Each test was conducted three times. The compressive strength test result was denoted as $\mathrm{F}_{\mathrm{lab}}$ and the device used is shown in Figure 3. It is important to note that the device and the standard used to test the compressive strength of the asphalt mix in this research are usually used for concrete testing. However, several steel plates were placed underneath the asphalt samples so that the asphalt samples could fit into the device.

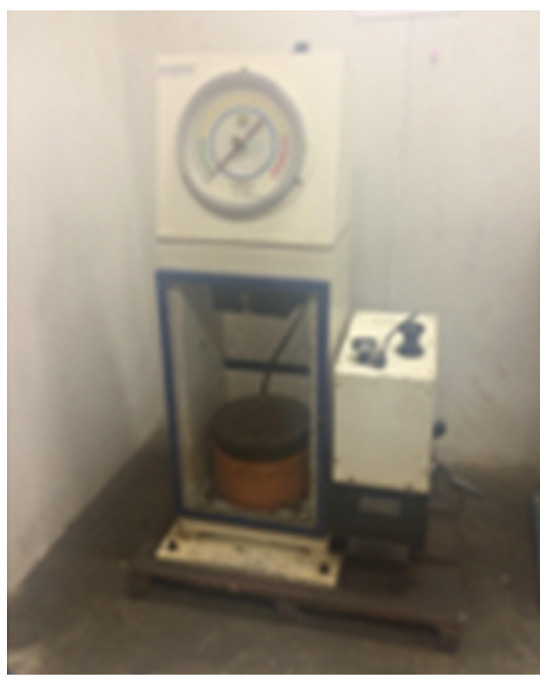

Fig. 3. Compressive strength test device 


\subsection{Overtopping calculation}

In calculating the wave overtopping to be used in this research, there are some assumptions made, including:

- the wave overtopping is assumed to fall perpendicular to the protection layer;

- the wave condition used in this research is based on the wave occurred at Southern Beaches of Java Island, Indonesia, including using three wave period (T) namely, 8, 10 and 12 seconds and using the incoming wave height were varied between 0.5 and 5 meters, with 0.5 meter interval;

- the wave overtopping hits against a plain vertical wall;and

- three cress freeboard $\left(R_{c}\right)$ heights were calculated, namely $0.7,1$, and 2 meter.

The overtopping debit is the volume of water that fall onto the inner slope of sea dike. In this research, there are two wave overtopping conditions considered, which are the impulsive and the non-impulsive conditions. A non-dimensional parameter, h*, was used to determine whether the wave overtopping was impulsive or non-impulsive and was calculated as follows:

$$
\mathrm{h}^{*}=1.3 \frac{\mathrm{h}_{\mathrm{s}}}{\mathrm{H}_{\mathrm{m} 0}} \frac{2 \pi \mathrm{h}_{\mathrm{s}}}{\mathrm{gT}_{\mathrm{m}-1}^{2}}
$$

where:

$\mathrm{h}_{\mathrm{s}}=$ water depth at the toe of the structure

$\mathrm{H}_{\mathrm{m} 0}=$ wave height at the toe of the structure

$\mathrm{T}_{\mathrm{m}-1.0}=$ wave period

If the $h^{*}$ parameter is more than 0.3 , the wave was categorized to be non-impulsive, and if the $\mathrm{h}^{*}$ parameter was less than 0.2 , the wave was categorized to be impulsive.

Based on the equations introduced by [20], for nonimpulsive wave, the wave overtopping debit was calculated based on the equation as follows:

$$
\frac{\mathrm{q}}{\sqrt{\mathrm{gH}_{\mathrm{m} 0}^{3}}}=0.04 \mathrm{e}^{\left(-2.6 \frac{\mathrm{Rc}}{\mathrm{H}_{\mathrm{m} 0}}\right)}
$$

where:

$\mathrm{q}=$ average overtopping discharge

$\mathrm{R}_{\mathrm{c}}=$ cress freeboard

For impulsive wave, the wave overtopping debit was calculated based on the equations as follow:

$$
\begin{aligned}
& \frac{\mathrm{q}}{\mathrm{h}_{*}^{2} \sqrt{\mathrm{gh}_{\mathrm{s}}^{3}}}=1.5 \times 10^{-4}\left(\mathrm{~h}_{*} \frac{\mathrm{R}_{\mathrm{c}}}{\mathrm{H}_{\mathrm{m} 0}}\right)^{-3.1} \\
& \frac{\mathrm{q}}{\mathrm{h}_{*}^{2} \sqrt{\mathrm{gh}_{\mathrm{s}}^{3}}}=2.7 \times 10^{-4}\left(\mathrm{~h}_{*} \frac{\mathrm{R}_{\mathrm{c}}}{\mathrm{H}_{\mathrm{m} 0}}\right)^{-2.7}
\end{aligned}
$$

Equation 3 was used when $0.03<{ }_{\mathrm{h}_{*}} \frac{\mathrm{R}_{\mathrm{c}}}{\mathrm{H}_{\mathrm{m} 0}}<1.0$ and equation 4 was used when $\mathrm{h}_{*} \frac{\mathrm{R}_{\mathrm{c}}}{\mathrm{H}_{\mathrm{m} 0}}<0.02$.
The calculated wave overtopping debit data was verified by using an online calculator [21], which was constructed based on the EurOtop Manual [22]. The debit was then converted to obtain the volume of water $\left(\mathrm{V}_{\text {bar }}\right)$ by using an equation introduced by [16], which is:

$$
\mathrm{V}_{\mathrm{bar}}=0.8 \frac{\mathrm{q}_{\mathrm{m}-1} \mathrm{~N}_{\mathrm{w}}}{\mathrm{N}_{\mathrm{cw}}}
$$

where:

$\mathrm{N}_{\mathrm{w}}$ = number of incoming wave

$\mathrm{N}_{\mathrm{ow}}$ = number of overtopping wave

Lastly, the $\mathrm{V}_{\mathrm{bar}}$ was then converted as compressive force $\left(F_{\text {wave }}\right)$, which was calculated by using the following formula:

$$
\mathrm{F}_{\text {wafe }}=\mathrm{V}_{\text {bar }} \times \rho \times \mathrm{g}
$$

where:

$\rho=$ density of water $=1000 \mathrm{~kg} / \mathrm{m}^{3}$

$\mathrm{g}=$ gravity $=9.81 \mathrm{~m} / \mathrm{s}^{2}$

The $F_{\text {wave }}$ was compared to the $F_{\text {lab }}$ to see whether the prepared samples could resist the calculated $F_{\text {wave }}$. $\mathrm{F}_{\text {wave }}$ calculated from Equation 6 was in $\mathrm{kN}$. To compare

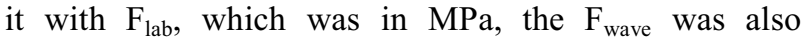
converted to $\mathrm{MPa}$ by dividing the value by the surface area of asphalt sample, which was $8167.14 \mathrm{~mm}^{2}$.

\section{Results and discussion}

\subsection{Characteristics of asphalt mixture}

Tables 3 and 4 show the characteristics of asphalt mixture made of limestone and coral aggregates, respectively. The characteristics measured including specific gravity, Void in Mix (VIM), Void in Mineral Aggregate (VMA), Void Filled with Asphalt (VFA), stability, flow, Marshall Quotient (MQ), and the compressive strength $\left(\mathrm{F}_{\text {lab }}\right)$. The values listed in Tables 3 and 4 are the average of the results of the three samples tested.

Table 3. Characteristics of asphalt mixture with limestone aggregates

\begin{tabular}{|c|c|c|c|}
\hline \multirow{2}{*}{ Characteristics } & \multicolumn{3}{|c|}{ Asphalt Content } \\
\cline { 2 - 4 } & $\mathbf{4 . 5 \%}$ & $\mathbf{5 . 5 \%}$ & $\mathbf{6 \%}$ \\
\hline Specific Gravity & \multicolumn{3}{|c|}{2.343} \\
\hline VIM (\%) & 3.97 & 2.08 & 3.27 \\
\hline VMA (\%) & 12.54 & 10.3 & 14.12 \\
\hline VFA (\%) & 69.82 & 78.67 & 76.81 \\
\hline Stability $(\mathrm{kg})$ & 3220 & 2208 & 2568 \\
\hline Flow $(\mathrm{mm})$ & 2.73 & 2.33 & 3.53 \\
\hline $\mathrm{MQ}(\mathrm{kg} / \mathrm{mm})$ & 1182 & 963 & 727 \\
\hline $\mathrm{F}_{\text {lab }}(\mathrm{MPa})$ & 62.41 & 126.46 & 97.90 \\
\hline
\end{tabular}

The data in Tables 3 and 4 shows that the coral aggregates have a higher percentage of VMA and VFA than the limestone aggregates, regardless of the 
percentage of asphalt content. This data suggests that the coral aggregates are more porous than the limestone aggregates. It can also be seen from the specific gravity values of both aggregates, which represent the density of the aggregates. The specific gravity of coral aggregates is approximately $36 \%$ lower than the specific gravity of limestone aggregates, which also suggest that the coral aggregates have more pores than the limestone aggregates.

Table 4. Characteristics of asphalt mixture with coral aggregates

\begin{tabular}{|c|c|c|c|}
\hline \multirow{2}{*}{ Characteristics } & \multicolumn{3}{|c|}{ Asphalt Content } \\
\cline { 2 - 4 } & $\mathbf{4 . 5 \%}$ & $\mathbf{5 . 5 \%}$ & $\mathbf{6 \%}$ \\
\hline Specific Gravity & \multicolumn{3}{|c|}{1.499} \\
\hline VIM (\%) & 3.71 & 3.04 & 5.46 \\
\hline VMA (\%) & 24.83 & 28.74 & 25.21 \\
\hline VFA (\%) & 84.95 & 89.62 & 82.10 \\
\hline Stability (kg) & 1692 & 1890 & 2137 \\
\hline Flow $(\mathrm{mm})$ & 3.40 & 4.60 & 3.33 \\
\hline MQ $(\mathrm{kg} / \mathrm{mm})$ & 490 & 411 & 644 \\
\hline $\mathrm{F}_{\text {lab }}(\mathrm{MPa})$ & 77.51 & 83.63 & 85.67 \\
\hline
\end{tabular}

After the samples were compacted, the percentages of VIM of all samples were similar, although the percentages of VIM of the asphalt samples made of limestone aggregates are slightly higher than the asphalt samples made of coral aggregates for all variety of asphalt content.

From the results presented in Tables 3 and 4, it can be seen that all samples have met the requirements stated in [23]. By analysing the stability, flow, and MQ values of all samples, it can be seen that asphalt samples made of limestone aggregates have a higher stability, a lower flow, and a higher MQ values than the asphalt samples made of coral aggregates, which suggest that the asphalt mixture with limestone aggregates is more stable and more resistant to permanent deformation than the asphalt mixture with coral aggregates.

\subsection{Compressive strength test $\left(F_{\text {lab }}\right)$ results}

The Compressive Strength Test results of the asphalt samples made of both aggregates are presented in Tables 3 and 4. There is a significant difference in the compressive strength of asphalt samples with limestone aggregates with the addition of asphalt. Increasing the asphalt content from $4.5 \%$ to $5.5 \%$ doubled the compressive strength of the asphalt samples with limestone aggregates, while increasing the asphalt content from $4.5 \%$ to $6 \%$ increased the compressive strength by approximately 57\%. However, this phenomenon was not found in the asphalt samples with coral aggregates. Increasing the asphalt content by $1 \%$ and $1.5 \%$ increases the compressive strength by approximately $8 \%$ and $11 \%$.

Furthermore, in general, the asphalt samples made with limestone aggregates with $5.5 \%$ and $6 \%$ asphalt content can resist more compression force than the asphalt samples made of coral aggregates, except the asphalt samples with $4.5 \%$ asphalt content. This could be related with the mineralogy of the aggregates. Structurally, coral aggregates have more pores than the limestone aggregates, which make the coral aggregates are not as strong as the (more) compact limestone aggregates. During the compaction process in the asphalt sample making, some of the coarse coral aggregates (aggregates I and II) might be crushed into finer particles. Adding more asphalt to the mixture will not help increasing the compressive strength by much as the asphalt would have already seeped through the void between aggregates and/or between the minerals. On the other hand, limestone aggregates are generally more compact than the coral aggregates, and hence, adding more asphalt to the asphalt mixture will improve the adhesion between the asphalt and the aggregates. However, adding too much asphalt to the mixture will have an adverse effect on the compressive strength. Too much asphalt will reduce the compressive strength as the force would be partially resisted by the asphalt, which is not as strong as the aggregates. In short, the more compact the mineralogy of an aggregate, the higher the force that could be resisted by the asphalt mixture made of those.

\subsection{Comparison between $F_{\text {lab }}$ and $F_{\text {wave }}$}

Based on the wave overtopping calculation explained in Section 4 , both $F_{\text {lab }}$ and $F_{\text {wave }}$ for $\mathrm{R}_{\mathrm{c}}$ of $0.7,1$, and $2 \mathrm{~m}$ were plotted in Figures 4, 5, and 6, respectively. The data points plotted in those figures include both nonimpulsive $F_{\text {wave }}$ (blue points) and impulsive $F_{\text {wave }}$ (green) for various height and period combinations and the magnitude is displayed in $\mathrm{x}$-axis. The division between impulsive and non-impulsive waves was made based on the parameter $h^{*}$ (equation 1). The black lines (straight and dashed) represent the $F_{\text {lab }}$ for asphalt samples with limestone aggregates and the red lines (straight and dashed) represent the $F_{\text {lab }}$ for asphalt samples with coral aggregates.

From the data shown in Figures 4, 5, and 6, it can be seen that the magnitudes of $F_{\text {wave }}$ depending on the height and the period of the incoming waves. The higher the height $(\mathrm{H})$ of the incoming wave, the more likely it is for the wave to become an impulsive wave, and the impulsive waves created higher compressive forces than the non-impulsive waves. The non-impulsive $F_{\text {wave }}$ data ranges between $0.002 \mathrm{MPa}$ and $0.665 \mathrm{MPa}$ for $\mathrm{R}_{\mathrm{c}}$ of 0.7 , 1 , and $2 \mathrm{~m}$. Additionally, it was found that the higher the cress freeboard, the lower the impact due to the force generated by the overtopping wave onto the protection layer of sea dike, which can be seen from the decreasing value of $F_{\text {wave }}$. For the sea dike with $R_{c}$ of $0.7 \mathrm{~m}$, the highest (impulsive) $\mathrm{F}_{\text {wave }}$ was above $250 \mathrm{MPa}$, while for the sea dike with $R_{c}$ of $2 \mathrm{~m}$, the highest (impulsive) $F_{\text {wave }}$ was (only) approximately $17 \mathrm{MPa}$. 


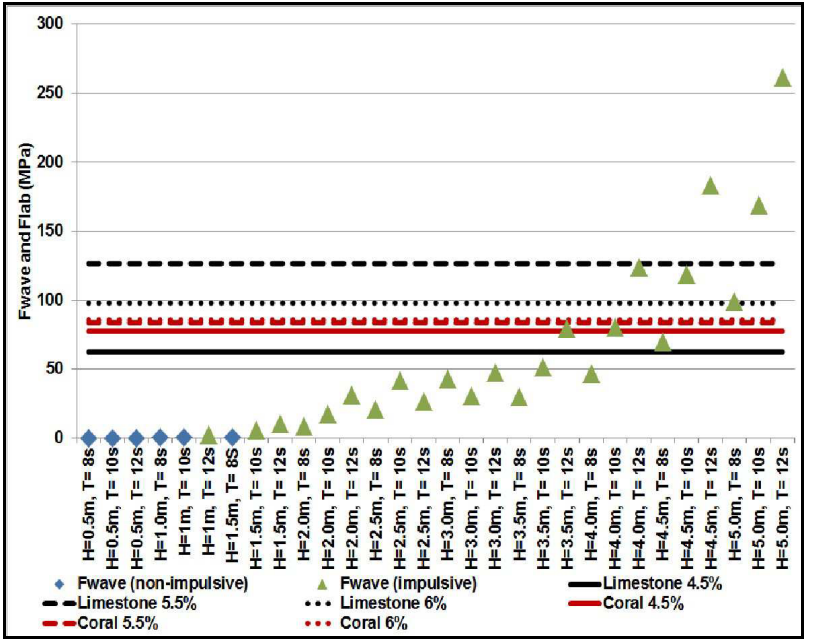

Fig. 4. The comparison between $F_{\text {lab }}$ and $F_{\text {wave }}$ for $R_{c}=0.7 \mathrm{~m}$

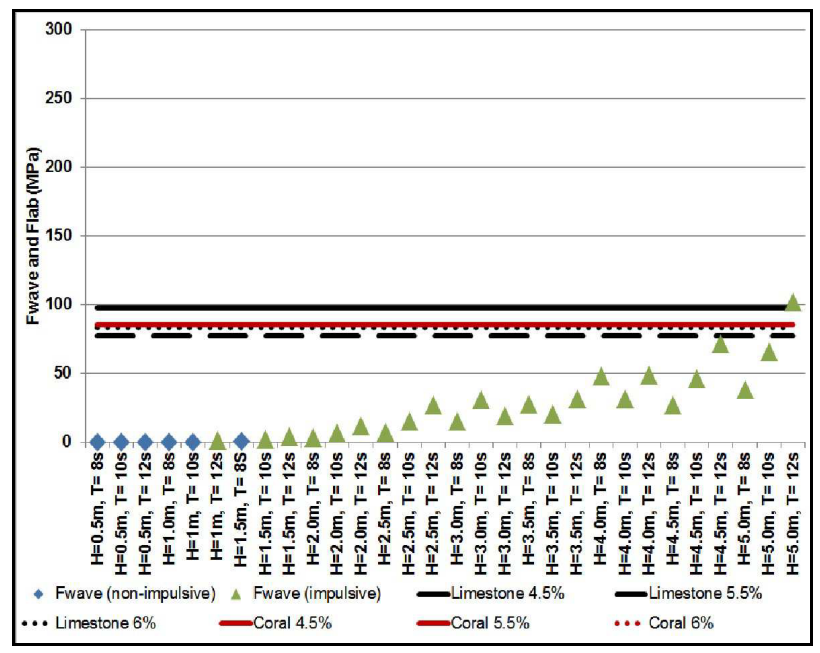

Fig. 5. The comparison between $F_{\text {lab }}$ and $F_{\text {wave }}$ for $R_{c}=1 \mathrm{~m}$

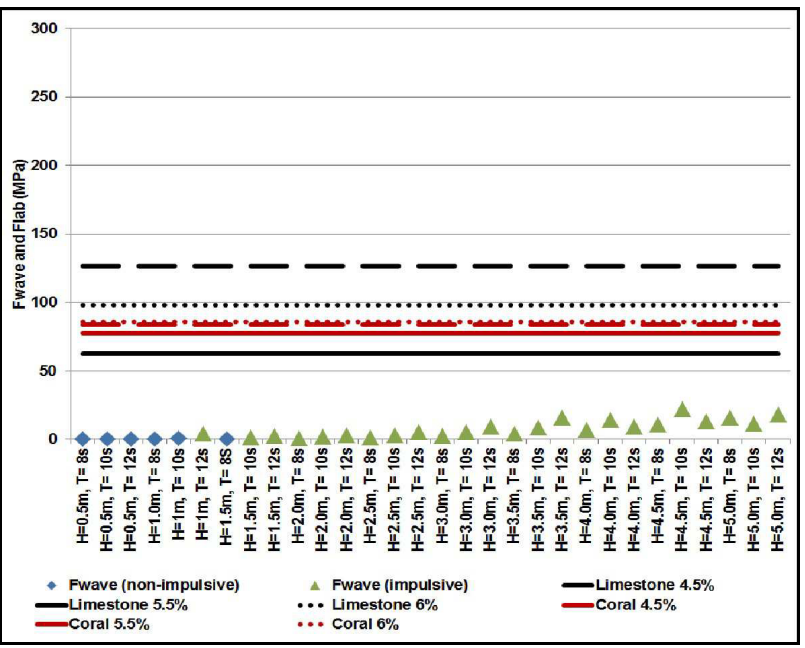

Fig. 6. The comparison between $F_{\text {lab }}$ and $F_{\text {wave }}$ for $R_{c}=2 \mathrm{~m}$

All asphalt mixtures with either limestone or coral aggregates could resist the $F_{\text {wave }}$ generated for sea dike with $R_{c}$ of $2 \mathrm{~m}$, as seen in Figure 6 . However, if the $R_{c}$ is $1 \mathrm{~m}$ and the wave height is $5 \mathrm{~m}$, only asphalt mixture with $5.5 \%$ asphalt content and limestone aggregates that could resist that wave.

\section{Summary and conclusions}

It is important for Indonesia as a maritime country to ensure that the infrastructure built around the coastline is resistant to the hydrodynamic forces from the waves. Due to the increasing construction cost, it is desirable to use locally available material, including coral and limestone aggregates. The main question of the paper is to analyse the feasibility of two natural aggregates, coral and limestone aggregates, as an ingredient of asphalt mixture to be used as the protection layer of sea dike structure against the overtopping wave.

In this research, asphalt samples with limestone and coral aggregates have been constructed to assess the compressive strength of the asphalt mixture. A calculation has also been made to predict the force due to wave overtopping that could occur. From the laboratory and calculation results, it can be concluded that:

- asphalt mix with 5.5\% asphalt content and with limestone aggregates have the highest compressive strength;

- both limestone and coral aggregates can be used as an ingredient of asphalt mixture, depending on the magnitude of the $\mathrm{F}_{\text {wave }}$ needs to be resisted;

- it is important to study the characteristics of the incoming wave to decide the height (and the type) of the sea dike to be constructed; and

- building a higher vertical wall could help in reducing the magnitude of the $F_{\text {wave }}$ needs to resisted, and hence, the protection layer could be built with, for example, coral aggregates.

The authors would like to thank Bina Nusantara University for the research grant provided to conduct this research.

\section{References}

1. I. Jassim, S. Tan, P. A. Vermeer, M. A. Hicks, Conference of the Association for Computational Mechanics in Engineering ACME (2012)

2. K. W. Pilarczyk, Dikes and Revetments: Design, Maintenance and Safety Assessment (1998)

3. S. Nandlal, Lightweight semi-flexible dike (1985)

4. J. van der Meer, Seawalls, dikes and revetments, ed. K.W. Pilarczyk (1998)

5. Committee on The Compaction of Asphalt Revetments of Dyke Slopes, Asphalt Revetments of Dyke Slopes (1977)

6. R. Devnita, Jurnal Geologi Indonesia 4, 1, p. 19-29 (2009)

7. A. Yamin, Jurnal Jalan - Jembatan 28, 3 (2011)

8. O. M. Ogundipe, Transportation Research Procedia, 14 p. 685-693 (2016)

9. D. Manglorkar, P. S. K. Kandhal, F. Parker, Evaluation of Limestone Coarse Aggregate in Asphalt Concrete Wearing Courses 1991, Auburn University Highway Research Center Alabama, United States of America (1991) 
10. F. Chairuddin, M. W. Tjaronge, M. Ramli, J. Patanduk, IACSIT International Journal of Engineering and Technology 8, 3 (2016)

11. N. A. Bowers, Engineering News Record, July p. 80-85 (1944)

12. Overseas Centre, A Guide to the Structural Design of Bitumen-Surfaced Roads in Tropical and SubTropical Countries, Transportation and Road Research Laboratory (1993)

13. J. Palmer, Use of Coral as an Engineered Construction Aggregate in Pacific Runways (2013)

14. H. Schlüttrumpf, J. van der Meer, A. Kortenhaus, T. Bruce, L. Franco, Handbook of Coastal and Ocean Engineering, ed. Y.C. Kim (2010)

15. J. W. van der Meer, J.P.F.M. Janssen, Wave Forces on Inclined and Vertical Wall Structures, ed. N. Kobayashi and Z. Demirbilek (1995)

16. L. Franco, M.d. Gerloni, J.W. van der Meer, Coastal Engineering p. 1030-1045 (1994)

17. M. R. A. van Gent, 28th Conference on Coastal Engineering (2002)
18. G. J. Steendam, J. W. van der Meer, B. Hardeman, A. van Hoven, International Conference on Coastal Engineering ICCE (2012)

19. W. Wati, Pengaruh Penambahan Bahan Alami Lateks (Getah Karet) Terhadap Karakteristik Campuran Hot Rolled Sheet Wearing Course (HRSWC) (2015)

20. T. Bruce, J.W. van der Meer, T. Pullen, W. Allsop, Wave Overtopping at Vertical and Steep Structure (2009)

21. HR Wallingford Ltd. Calculation Tool, Available from: http://www.overtopping-manual.com/aboutthis-site.html (2007)

22. T. Pullen, N. W. H. Allsop, T. Bruce, A. Kortenhaus, H. Schlüttrumpf, J. W. van der Meer, EurOtop Wave Overtopping of Sea Defences and Related Structures: Assessment Manual (2007)

23. Direktorat Jenderal Bina Marga, Dokumen Pelelangan Nasional - Penyediaan Pekerjaan Konstruksi (Pemborongan) Untuk Kontrak Harga Satuan (2010) 